\title{
Citizens Committees and Local Elites: Elite Capture, Captured Elites, and Absent Elites in Health Facility Committees
}

\author{
Jean-Benoit Falisse ${ }^{1} \oplus \cdot$ Hugues Nkengurutse $^{2}$
}

Accepted: 12 July 2021 / Published online: 23 August 2021

(c) The Author(s) 2021

\begin{abstract}
Mainstream development policies often promote citizens committees to oversee basic social services. Such committees require influence over, and legitimacy among, service providers and citizens to perform their roles, which local elites can help or hinder. Using a mixed-methods approach, we analyse the situation in 251 health facility committees in Burundi, part of which benefited from interventions designed to bolster their relationship with local leaders. Interviews and focus groups reveal that leaders' support is essential for committees to access citizens and work with nurses, but the failure of the interventions show it is hard to nurture. The local socio-political elites (politicians, faith leaders) bypass and ignore the committees. In a 'fragile' context such as Burundi's, the lack of political elite capture attempt suggests a largely vacuous committee system. The committees remain a façade participatory institution. Understanding and engaging with local everyday local politics is crucial for committee-based development approaches.
\end{abstract}

Keywords Social accountability $\cdot$ Community participation $\cdot$ Elite capture $\cdot$ Primary health care $\cdot$ Fragile- and conflict-affected states $\cdot$ Burundi

\section{Résumé}

Les politiques de développement encouragent souvent l'implication de comités citoyens dans le suivi des services sociaux de base. Pour jouer leur rôle, de tels comités nécessitent une influence et une légitimité parmi les prestataires de services et parmi les citoyens, ce que les élites locales peuvent appuyer ou entraver. En utilisant des

Jean-Benoit Falisse

jb.falisse@ed.ac.uk

Hugues Nkengurutse

nkengurutsehugues@gmail.com

1 Centre of African Studies, University of Edinburgh, 15a George Square, Edinburgh EH8 9LD, UK

2 Faculté des sciences sociales et politiques, Université du Lac Tanganyika, Bujumbura, Burundi 
méthodes mixtes, nous analysons la situation dans 251 comités de santé au Burundi, dont une partie a bénéficié d'interventions visant à renforcer leur relation avec les leaders locaux. Les entretiens individuels et collectifs révèlent que le soutien des leaders locaux est essentiel pour que les comités accèdent aux citoyens et travaillent avec les infirmier.ères, mais l'échec des interventions montre que ce soutien est difficile à susciter. Les élites sociopolitiques locales (figures politiques, chefs religieux) contournent et ignorent les comités. Dans un contexte « fragile » tel que celui du Burundi, 1 'absence de tentative de captation par les élites politiques suggère que le système des comités n'est qu'une coquille vide. Les comités restent une institution participative de façade. Comprendre et s'investir dans la politique locale quotidienne est crucial au succès des approches de développement basées sur les comités citoyens.

\section{Introduction}

Since the 'good governance' turn of the 1990s, community participation and social accountability have been at the core of mainstream development programmes and policies. Driven by the idea that citizens' oversight contributes to making services work in the population's best interest, governments and aid organisations have set up a wide range of participatory institutions at the level of basic social services (e.g. Manor 2004; Sabates-Wheeler et al. 2020). However, such institutions do not exist in a socio-economic and political void. Policy-makers and researchers recurrently observe and worry that participatory mechanisms, such as citizens committees tasked with the monitoring and joint management of public services, are captured by local elites who have limited interest in the issues ordinary citizens face. This paper empirically explores the interactions between local elites and elected committees in charge of co-managing primary health-care facilities in Burundi (the Health Facility Committee or Comité de Santé, HFC). We discuss the local "small p politics of accountability" (Guerzovich 2020) and focus on the possibility of an 'elite co-opt' approach (Wong 2012) whereby local elites are mobilised to support development projects (Platteau and Gaspart 2013).

We find HFCs to be of limited efficiency. Committees counting better educated or wealthier individuals or individuals with more social capital are not significantly better organised or associated with better functioning primary Health-care Facilities (centres de santé, HFs). The better-off citizens who make up the committees are 'generic' representatives, a form of socio-economic elite who is not the locally influential political elite. Nested qualitative research shows that the HFC never becomes a major player in local life; attempts to enhance the HFC legitimacy and effectiveness by linking it up with local political leaders are quickly discontinued. The committee does not command enough authority to summon the key local players-or even the population. The findings question the short-term potential of HFCs in topdown, authoritarian, post-conflict societies such as Burundi's.

The following section briefly discusses some of the literature on the role of local elites in participatory service delivery from the perspective of public health, development studies and economics, and Burundi area studies. The HFC institution is then introduced, followed by the conceptual framework and hypotheses 
that guided the research. The last sections present quantitative, experimental, and qualitative evidence of the effects of elite support (and the lack thereof) on the functioning of HFCs and health facilities.

\section{Counter- Versus Co-opt-elite?}

Citizens committees are, by definition, embedded within economic, cultural, and social systems; they are influenced by and may reproduce existing power dynamics (Rusca et al. 2015).

The public health literature has long highlighted the challenge for the HFCs not to reflect structures of domination, including by the wealthy and men. To cite but a couple of studies, Ramiro et al. (2001)'s work showed the Philippines' HFC system mostly comforted the position of local elites and authorities, while Sepehri and Pettigrew (1996) highlighted that health committee members in Nepal did not reflect the view of villagers who elected them. In practice, and sometimes despite an official discourse of inclusiveness, local leaders often seek to limit non-elite participation in committees (McCoy et al. 2012).

The theoretical and empirical literature in development studies and economics underlines that participatory projects can create opportunities for local elites to establish or develop their patronage networks (Rajasekhar et al. 2018). Platteau suggests that local leaders must be 'disciplined' for aid provided through participatory institutions to be efficient; therefore, he invites funders to set up coordination and reputation mechanisms to avoid aid embezzlement by local elites (Platteau 2004; Platteau and Gaspart 2013). New institutions create a new space for delivering basic social services or commodities, but there is no reason to believe that existing local elites would not attempt to occupy that space. Looking at a major community-driven project in Indonesia, Dasgupta and Beard (2007) find that benefits for the poor are lower whenever the local political elite controlled decisions. Such 'elite capture' - a situation where elites take advantage of their positions to amass resources or benefits to the detriment of the larger population-has led many policy-makers to favour a 'counter-elite' approach in which elites are, as much as possible, excluded from participatory institutions.

A different view is taken by a smaller stream of the literature that has argued that local leaders not only cannot be bypassed but could also play a positive role by publicly supporting participatory institutions. Wong (2012) names the concept 'co-opt-elite' as the participatory institution is deliberately 'absorbing' local elites. Warren and Visser (2016) allude to a similar idea when pointing to cases of 'captured elites' in Indonesia; elites can be pragmatically used to channel and access resources. Although they do not argue in favour of the co-opt-elite approach per se, Mansuri and Rao (2004) stress that not all elites are greedy, some can be benevolent. Dasgupta and Beard (2007) establish a distinction between elite capture and elite control, with the latter not necessarily implying misappropriation. 


\section{Local Elite and Health Facility Committees in Burundi}

In the context of Burundi, different authors have highlighted the development of patronage networks related to local politicians and civil servants (Uvin and Bayer 2013; Vandeginste 2015). Most of the literature focuses on the macro-level situation. Vandeginste (2015) finds a "historical continuity between the post-conflict polity and the traditional patronage system which structured societal relations from the king down to the peasant" (19), while Uvin and Bayer (2013) describe a context where traditions of transparency and bureaucratic autonomy are not deeply internalised. Micro-dynamics of patronage and elite capture, especially those happening at the root level of representation, the hill (colline, whose chief is elected), are left largely unexplored and described in broad terms as a 'culture of the chief' (Laely 2014). The extent of elite capture in public and poorly funded health centres and schools is not well documented.

Health Facility Committees, which are made of elected community members who are tasked with the co-management of primary health-care facilities (HFs), are the quintessential mechanism of community participation in low-income countries (McCoy et al. 2012), and especially in Africa where they have been actively promoted as part of the 1987 Bamako Initiative sponsored by UNICEF and the World Health Organisation. Laws and Ministry of Health guidelines regulate the HFCs of Burundi: each publicly-funded primary $\mathrm{HF}$ must have an HFC tasked with the co-management of the HF and reflecting the "voice of the population". There are, however, doubts as to whether this system is effective. Indeed, the scant research in Burundi has noted that HFC members are rarely supported and aware of their tasks and roles and that there is an apparent disconnect between the HF staff, the catchment area population, and their committees (Falisse et al. 2012; Niyongabo et al. 2018).

To play their role, HFC members need to know about their entitlements and tasks and the tools at their disposal for HF co-management and monitoring. They also need to have the genuine possibility to influence the HF, which stems not only from their knowledge but also depends on "systematic asymmetries of power inherent in unequal societies" (Osmani 2008, p. 38). Pointing to the negligible influence of committee members at their HF (Falisse et al. 2012; Niyongabo et al. 2018), the research on HFC in Burundi suggests a power gap: HFC members have limited influence over HF staff members. By throwing their weight behind the committee, local elites may potentially help narrow such a gap.

\section{Empirical Approach}

A mixed-methods experimental approach was developed to explore the role of local elites in HFC functioning and HF management, both in terms of 'capturing' the committee and in terms of supporting it and making it more influential or legitimate at the HF. 
The research is built on the evaluation of two interventions implemented by the NGO Cordaid in collaboration with the local NGO COPED and the Ministry of Health of Burundi, with the financial support of the European Union. They aimed to empower HFCs in $251 \mathrm{HFs}$ of Burundi between the end of 2011 and the end of 2013. The interventions were motivated by health financing reforms that had given HFs more direct control over their resources (Falisse 2019) and reiterated that the pre-existing HFCs are a core mechanism to ensure that such resources are spent in the population's best interest. The reform, however, had done very little to reinforce the committees (Falisse and Ntakarutimana 2020). The present study and research protocol were informed by (1) preliminary qualitative fieldwork on what could be done to strengthen the HFCs, carried out with HF staff, HFC members, local leaders, and health authorities in 48 sites; as well as (2) the discussion of the preliminary results and suggested interventions with academic researchers, NGOs, HFC and HF representatives, and the Burundian authorities. The Burundi research and ethics committee validated the research design (including the definition of the outcome variables of interest in advance of the evaluation). ${ }^{1}$ The authors trained and hired research assistants and enumerators who supported the qualitative and quantitative research. All had previous experience carrying out research, and we ensured they represented a wide variety of profiles (age, gender, ethnicity, academic background, urban/rural). The piloting of the interventions meant that 84 randomly selected HFCs did not receive any intervention for a year and served as a control group.

The first intervention (henceforth, training intervention) consisted of the training of HFC members on their role as per official guidelines, the functioning of the $\mathrm{HF}$, and the way for them to access and visualise information on the activities and finances of their HF (Falisse and Ntakarutimana 2020). It lasted for two days and was followed, in the subsequent months, by two follow-up re-cap sessions.

The second intervention came on top of the first one. It facilitated, through joint meetings, HFC members and local leaders to talk and know each other, with the hope that they would eventually collaborate. It echoed findings from the preliminary research, during which HF users had highlighted that a strong committee is one that is in contact with the local authorities and is known by them. The population, nurses, and HFC members alike had explicitly stressed that the connections and the composition of the HFC matter. Altering the composition of democratically elected committees was not an option, but attempting to strengthen their bonds with local stakeholders through organising meetings was a possible intervention. It had been suggested as potentially useful by some HFC members. Joint meetings were organised in 42 randomly selected committees that had received the training intervention bundle. In the first step, on the occasion of the training intervention, HFC members were asked to name ten local leaders whom they thought would facilitate the work

\footnotetext{
${ }_{1}$ It was, however, not formally registered. In another paper (Falisse \& Ntakarutimana, 2020), we look at cases where only part of the training intervention mentioned in this paper is delivered. In the present paper, we mainly compare the HF/HFCs that benefited from the full training set with those that benefited from this full set and the joint meeting.
} 
of the HFC if they knew more about the HFC. The second step was the organisation of the joint meeting between HFC members, HF staff, and these local leaders. Programme assistants facilitated the meetings. There was no attendance fee for participants. The meeting was an occasion for HFC members to introduce themselves and their work and get closer to selected leaders.

\section{Data Sources}

While the information on HF services was available on a monthly and yearly basis through the National Health Information System, little was known about the functioning of the HFC and the actual management of HFs. Survey instruments were developed with and deployed through a team composed of professional enumerators from Bujumbura and locally trained local community organisation members active near, but not in, the surveyed areas. The chief nurse, HFC president, and HF executive team were surveyed in each HF, both before and after the interventions. Thirty households were also surveyed in half of the HFs at baseline level (selected at random, with a proportional number of HFs in each intervention group) and in all the HFs at end-line, 1 year after the beginning of the interventions.

The research also entailed substantial qualitative research, which proved especially important to understand the local dynamics at play. Nested qualitative research (Lieberman 2005) was carried out by the authors and research assistants in twelve different sites where the joint meeting intervention was implemented, in 36 sites where only the training sessions were organised, as well as in 12 control sites. The criterion for nesting was the self-evaluation of the HFC efficiency during the last recap session of the training intervention. In each site, semi-structured interviews and focus groups with nurses, local leaders, citizens, and HFC members were conducted. The focus was on the functioning, actions, and influence of the committee, as well as its relationship with local leaders and HF staff. The data were analysed looking for key patterns (of which we provide illustrative quotes). As all mixed-methods work, there is only space for presenting a small part of both the qualitative and quantitative material collected.

\section{Analytical Approach and Evaluation Framework}

The first section of the results looks at the composition of the committee, mainly through descriptive statistics. The second section is the evaluation of the two interventions, for which we use a difference-in-difference model. Standard errors are clustered at the HF level in the case of individual-level data, and $p$ values are adjusted for multiple hypotheses testing (FWER). We add controls and use ANCOVA models to check robustness (McKenzie 2012).

Faced with a potentially very high number of variables-since concepts like social accountability or HF management are not easily captured by one indicatorour approach has been to develop dimensions or indexes, in line with Casey et al. (2012). They reflect (1) the organisation of the HFC according to the official guidelines, and also four aspects directly related to the influence of the HFC: (2.1) what 
Table 1 Characteristics of HFC members, executives, president, and the general population

\begin{tabular}{|c|c|c|c|c|}
\hline & $\begin{array}{l}\text { HFC (all) } \\
(2011)\end{array}$ & $\begin{array}{l}\text { HFC executives }^{a} \\
\text { (2011) }\end{array}$ & $\begin{array}{l}\text { HFC president } \\
\text { (2011) }\end{array}$ & $\begin{array}{l}\text { Burundi } \\
\text { (2011 census) }^{b}\end{array}$ \\
\hline Women (ratio) & $0.35(0.35)$ & $0.29(0.26)$ & $0.08(0.28)$ & 0.51 \\
\hline Speaks French (ratio) ${ }^{\mathrm{d}}$ & $0.40(0.32)$ & $0.78(0.25)$ & $0.86(0.35)$ & 0.06 \\
\hline Secondary Education (ratio) & $0.32(0.21)$ & $0.65(0.24)$ & $0.77(0.42)$ & 0.08 \\
\hline Returnee/repatriate (ratio) & $0.08(0.17)$ & $0.03(0.18)$ & $0.08(0.27)$ & 0.06 \\
\hline Internally displaced (ratio) & $0.08(0.23)$ & $0.07(0.18)$ & $0.07(0.25)$ & 0.02 \\
\hline Not subsistence farmer (ratio) & $0.29(0.24)$ & $0.53(0.35)$ & $0.70(0.46)$ & 0.10 \\
\hline Age (mean) & Not available & $39.6(6.53)$ & $41.6(10.01)$ & 35.69 \\
\hline Elected politician (ratio) & $0.15(0.17)$ & $0.38(0.21)$ & $0.23(0.42)$ & $<0.001^{\mathrm{c}}$ \\
\hline Religious leader (ratio) & Not available & 0.07 & 0.09 & $<0.001^{\mathrm{c}}$ \\
\hline
\end{tabular}

Standard deviation in parentheses

${ }^{a}$ Vice-president, treasurer, secretary, and sometimes a couple of other named positions

${ }^{\mathrm{b}}$ In the adult population (18 and above)

${ }^{\mathrm{c}}$ No figures available, based on an estimate of the number of faith-based institutions and public offices

${ }^{\mathrm{d}}$ Language of the elite in Burundi

it decides on at the HFC, (2.2.) the level of information it gets and shares, (2.3) the extent to which it is known and interacts with the population, and (2.4) the extent to which basic accountability procedures, supposedly the core work of the HFC, are implemented at the HF. In addition, we also consider (3) whether the management of the HF has changed. Each dimension is the sum of the unweighted mean of $z$-scores for each observation and comprises a set of variables explained in the Appendix (Table 4). ${ }^{2}$ The third section investigates heterogeneous effects, especially whether the HFC membership makes it more reactive to the training intervention (the statistical power for such analysis is, however, very limited). ${ }^{3}$ More importantly, perhaps, the section goes back to the qualitative data to give a more detailed description of the position of HFC members vis-à-vis the local elite.

The impact evaluation component takes an important place in the paper. However, in a context where the interventions had mostly null effects, it is the qualitative data analysis that likely provides the most insightful evidence on the relationship between participatory institutions and local elites.

\footnotetext{
${ }^{2}$ In this paper, we focus on the dimensions that are expected to be the first one to change and (since they do not change) do not look closely at the use of HF services. See First Falisse \& Ntakarutimana (2020) for a discussion.

3 Using the baseline values of dimension 2.1, a 0.25 standard deviation change had a power of only 0.628 (alpha 0.05).
} 


\section{Findings and Discussion}

\section{Membership and Situation of the Committees at Baseline}

As shown in Table 1, HFC presidents, executive members, and even ordinary members are better off in socio-economic terms than the average Burundian citizen. Dominant categories of the population-men, people with a secondary school degree, civil servants - are also overrepresented in HFCs.

The profiles of the HFC members are very much in line with research on HFCs and citizens committees in general and around the world (Mansuri and Rao, 2012; or more recently on farmer organisations: Minah and Malvido Pérez Carletti 2019). They indicate that better-off individuals - a socio-economic elite in the sense of people who could be considered in a better position because of their education, social standing, or wealth-sit in the committee. However, as the rest of the paper will show, it neither necessarily means that such socio-economic elites are also necessarily the political elites in the sense of those who hold power locally, nor does it mean that Burundi's HFCs are captured to the interest of the better-off individuals who sit in them. Three points are worth highlighting.

Firstly, our survey and interview data show that, while the population did elect HFC members, many HFC members had not actively planned or even sought to be elected. $7.39 \%$ of the HFCs even declared that there were more seats in the committee than candidates at the last HFC elections. Participants in a focus group with HFC members in the west of the country summed up what appears to be the situation often:

We were not really candidates. We were chosen [by the population present that day], and we were happy with that. The Health District team came the day of the election with the chief nurse, and they explained what the committee is about. (Focus Group [FG] HFC, reference B05, 2013).

Secondly, what the capture would have been of is somewhat unclear. The HFCs functioned very poorly at the time of the baseline study: as Table 2 clearly shows, HFC members had little say in HF affairs, no understanding of their roles, and no information on the situation at their HFs. Overall, the situation seemed to be one where the committees exist in name only. The interventions described in the following section sought to change this situation.

Thirdly, while interviewees emphasised being motivated by the idea of service to the community and improving access to health, they also mentioned economic motivations, social status, and consideration. They did not explicitly or implicitly mentioned capturing rents (perhaps also because one-off interviews are prone to socially desirable answers), but did talk of their hope to get preferential access to health care, access other positions in the community, and maybe receive monetary incentives for their work-even though they also acknowledged that HFC positions are not meant to be paid. They also repeatedly explained that it is "wellregarded to be an HFC member" (FG HFC, B11, 2013). That HFC members state that they are after some extra social status may suggest that they are not quite the 
Table 2 Situation at baseline (mean values)

(1)

(2)

(3)

Control group Training group Training + meeting group

Basic controls

'Collines' represented in HFC

$\begin{array}{lll}5.220(0.318) & 5.214(0.395) & 5.738(0.464) \\ 11.146(0.492) & 10.571(0.685) & 11.714(0.821) \\ 0.343(0.019) & 0.346(0.027) & 0.355(0.029) \\ 0.324(0.025) & 0.316(0.030) & 0.328(0.036) \\ 6.133(0.321) & 5.762(0.321) & 5.786(0.474) \\ 14,569(1041) & 14,756(1460) & 15,142(1283) \\ 0.193(0.044) & 0.190(0.061) & 0.214(0.064) \\ 0.940(0.011) & 0.938(0.027) & 0.952(0.012)\end{array}$

Number of HFC members

Ratio of women in HFC

Ratio of HFC went to secondary school

Support staff at HFC

Population in catchment area

Faith-based HF (still state funded)

Availability of 7 key services ${ }^{a}$

Situation with the HFC at baseline

Terms of Reference available

$0.217(0.046)$

$0.381(0.076)^{*}$

$0.262(0.069)$

HFC main responsibility: co-manager ${ }^{b}$

$0.148(0.040)$

$0.095(0.046)$

$0.146(0.056)$

HFC main responsibility: sensitisation ${ }^{\mathrm{b}}$

$0.691(0.052)$

0.738 (0.069)

$0.659(0.075)$

HFC main responsibility: link

$0.160(0.041)$

$0.167(0.058)$

$0.195(0.063)$ population $^{\mathrm{b}}$

Rights (0-2) at HF: HFC president ${ }^{\mathrm{c}}$

"HFC management committee"c

$\begin{array}{lll}0.484(0.043) & 0.476(0.059) & 0.473(0.050) \\ 0.392(0.043) & 0.347(0.056) & 0.412(0.057) \\ 0.179(0.032) & 0.214(0.040) & 0.163(0.037) \\ 0.157(0.040) & 0.143(0.055) & 0.143(0.055) \\ 0.120(0.036) & 0.143(0.055) & 0.071(0.040)\end{array}$

Balance sheet shared with $\mathrm{HFC}^{\mathrm{d}}$

Development plan shared with $\mathrm{HFC}^{3}$

Outcome indexes (details in Table A1)

1. HFC organisation

2.1. Accountability: decision rights

$$
\begin{array}{lll}
0.008(0.030) & 0.001(0.040) & 0.014(0.029) \\
0.000(0.066) & 0.061(0.100) & 0.026(0.083) \\
-0.000(0.046) & -0.026(0.056) & 0.014(0.077) \\
-0.041(0.044) & -0.042(0.050) & -0.064(0.062) \\
0.026(0.043) & -0.001(0.041) & 0.043(0.037) \\
0.000(0.043) & -0.027(0.045) & 0.034(0.055) \\
83 & 126 & 42
\end{array}
$$

Standard deviation in parentheses I stars in columns 2 and 3 denote statistical difference relative to the control group

a24-h resident service, minor surgery, maternal and child health services, pharmacy, laboratory services, referral, hospitalisation, and preventive care

${ }^{\mathrm{b}}$ According to HFC (open question, re-coded)

${ }^{c}$ With 0: no say at all in the HF management, 1 is invited to give their opinion, and 2 is actively involved in decision-making. According to the chief-nurse, similar results are found on average when asking the HFC president

${ }^{\mathrm{d}}$ According to the chief-nurse

$p$-values significance level (t test): $*<0.1, *<0.05, * * *<0.001$ 
Table 3 Local leaders picked by the HFC and present at the joint session (training + meeting group only)

\begin{tabular}{llll}
\hline Type of leader & $\begin{array}{l}\text { Mean ratio } \\
\text { per HFC }\end{array}$ & Standard deviation & Atleast one picked \\
\hline Low-level religious (assistants, 'catéchiste') & 0.238 & $(0.177)$ & 0.805 \\
High-level religious (priest, pastor, imam) & 0.108 & $(0.174)$ & 0.463 \\
Low-level local politician (colline, sous-colline) & 0.320 & $(0.223)$ & 0.854 \\
High-level local politician (zone and above) & 0.078 & $(0.165)$ & 0.317 \\
Teacher, school director & 0.094 & $(0.190)$ & 0.366 \\
Local civil society figure & 0.126 & $(0.190)$ & 0.488 \\
Community Health Worker & 0.031 & $(0.083)$ & 0.146 \\
Local 'wise men' (bashigantahe) & 0.006 & $(0.028)$ & 0.049 \\
\hline
\end{tabular}

most influential in their communities. Other elements that we will soon present also point in this direction.

\section{Support from Outside}

Before exploring the effects of the two interventions, it is useful to go back to the implementation of the joint meeting intervention. The HFCs were asked to pick key local figures of their HF catchment area they wanted to meet (Table 3). Local politicians and church representatives, the key local leaders playing an influential role in local politics, were the most frequently selected, suggesting they might be the most helpful or supportive. Civil society is the third pick of the HFC. Interestingly, the bashigantahe, the 'wise men' who sometimes act as customary judges, are nearly absent, thereby confirming a trend already highlighted in the literature that their sway has become very limited (Kohlhagen 2009).

The session facilitators did not collect more information on the profiles of the selected local leaders. Still, they reported that the overwhelming majority appeared fluent in French and educated to secondary level. Almost by design, they were also more likely than HFC members to hold power: $75 \%$ of them had political or religious appointments (versus $45 \%$ of HFC executives). While it may well be that local leaders are indeed slightly better off than HFC members when using the indicators of Table 2, the key difference was probably on a dimension that is harder to quantify: their level of influence in the local community.

Turning to the interventions, Fig. 1 presents the main effects relative to the control group. In the case of the training intervention, only the HFC organisation appeared to change, suggesting that information and capacity-building training were not enough to make the HFC a key player at the HF. It is worth noting that the training and follow-up sessions all took place as planned, and the HFC members' understanding of the content of the training was not reported an issue. The situation is slightly different in the case of the group of HFCs that also benefited from the joint meeting intervention. There, HFC decision rights increased, while the surveyed population seemed to indicate a less transparent experience at the HF. However, these 


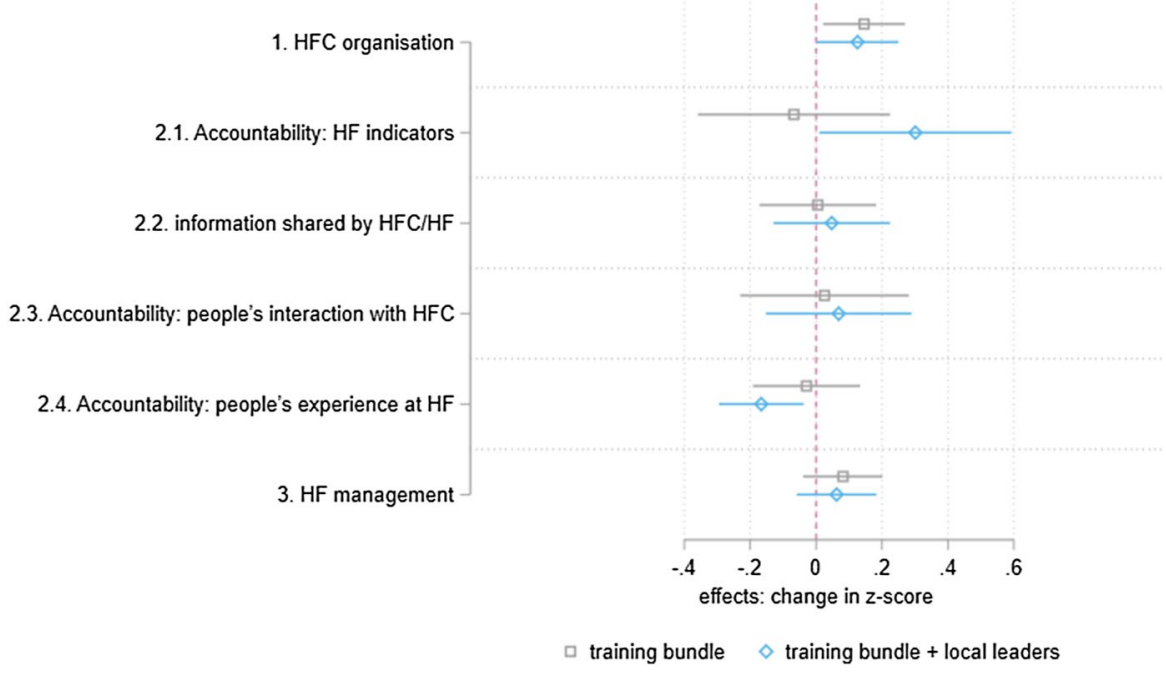

Fig. 1 Effects of the interventions

Effects are all relative to the control group; lines are standard errors. If the line touches the dotted red vertical line, the effect is not statistically significant at $p<0.1$. See Table 5 for details

findings are generally not robust to alternative specifications, and especially to multiple hypotheses testing (see Table A2).

Looking more closely at the different components that make up the two social accountability sub-indexes that are most significantly affected, a finer-grained picture emerges. As Table 6 in the Appendix shows, the change in the HFC's rights at the $\mathrm{HF}$ are mostly related to (1) the way the $\mathrm{HF}$ medical staff perceives the role of the HFC and (2) the role of the HFC executive members rather than ordinary members or the president. This supports the idea that the HFC may indeed slightly benefit from local leaders' support to appear legitimate in the eyes of the medical staff. It also suggests that such intermediation of the local political elite is primarily in favour of those who are the leading voices in the committee. At the household level, there is not a single variable that is significant: the effect is one of an overall less transparent experience when visiting the HF.

Overall, the gains from the interventions are negligible. Even the HFCs that reportedly acquired more say that their HFs are still far from being a core actor at the HF: on average, the HFC presidents that benefited from the joint meeting intervention are involved in only $17.6 \%$ (SD 28.1\%) of the decisions at their HF. ${ }^{4}$ This failure of the HFC strengthening programme does, however, reveal key elements of the HFC-elite relationship, which we explore through the qualitative data.

The initial meetings did take place in all the targeted HFs except one, but difficulties quickly emerged. Firstly, HFC after HFC, members insisted that for the meeting

\footnotetext{
4 They are consulted in $56.1 \%$ (SD 26.2) of the cases. Average over 7 domains of decision (see table A1), according to HFC president.
} 
with the local leaders to happen, the programme facilitation team-rather than the HFC members themselves-would need to send out invitations. This change in the original plan reveals the complexity of setting up a reunion and accessing local leaders in rural Burundi: HFCs, even when strengthened in their organisation and knowledge, simply do not command enough authority to summon local leaders. Secondly, attendance at that first meeting was an average of 7.731 local leaders out of the ten expected turned out (SD: 2.294). The lack of financial incentives was brought up to explain the variance in attendance at the joint meeting - in one instance, the HFC president even actively discouraged local leaders from coming because they would not be paid.

Unsurprisingly, 6 months after the intervention, only two HFCs had organised another meeting. Two main explanations emerge from the qualitative research. In many low and middle-performing HFCs, members felt they were still not in a (social and financial) position to invite local leaders and organise a meeting without external support. Tensions were reported important between the chief nurse, the local leaders, and the HFC, especially after the initial training. Those tensions were about the possibility of the HFC having a say in HF affairs, and the interviews and focus groups all pointed to the difficulty of the HFC to be taken seriously or seen as legitimate by the chief nurse and local leaders. In one HF, for instance, a staff member explained that: "until now, we disagree [with the HFC] about the control of finances and drugs; so we gave up on it [the HFC]" (interview HF chief-nurse, B33, 2013). Even when the chief nurse worked in full collaboration with the HFC, engaging with local leaders was not easy. As one chief nurse recalled: "I work with various partners: I had even planned to meet with the representatives of the churches, but they have not come to the meeting. I carry on, though" (interview HF chief-nurse, B48, 2013). An HFC president elaborated:

We could meet the local leaders once only. We are leaders-among us are primary school teachers who work really well-but we are not accepted by the rest of the local leaders. It is very hard; we really need to ask the authorities [permission] to talk [to the population] and do our work at the HF. They are the ones who have the power to give us the authorisation to talk. (interview HFC president, B47, 2013).

In the much smaller group of better-performing HFCs, the meetings are described as "not necessary" or "not necessary anymore" because the contact has been initiated and the new channels of communication are informal: local leaders and HFC members know each other and keep track of each other's action through informal chats. This explanation is consistent with the reportedly overwhelming number of local formal committee meetings suggested or imposed by third parties such as government's agencies or NGOs.

Overall, the failure of the joint meeting intervention reveals how the 'true' local leaders simply do not have much interest in the HFC. This lack of interest is problematic for the HFC for two reasons: first, it prevents them from accessing the population and, second, it likely weakens their position vis-à-vis chief nurses and the HF in general. Externally engineered meetings do not appear to change such equilibrium. 


\section{Support from Within?}

Counting local leaders in the HFC is typically seen as an advantage by the population as "they command respect and can transmit messages without any problem" (FG HFC, A11, 2013). Looking at our baseline data, HFC that counts a lot of local politicians appear, however, less likely to interact with citizens and less likely to be well organised (Table 7 in the appendix) - as we suggest below, a possibility is that such committee does not organise (as a committee) because there is a more obvious way to reach the population and influence HF management: the direct interference of local political figures. We found no evidence that the membership of the committee significantly affects the interventions described above (see Fig. 2). Of course, membership is an endogenous variable: committee members are chosen by the population and may, therefore, incarnate a form of consensus about the importance of the committee that may not change until HFC members are replaced.

In fact, qualitative research reveals HFC members who are more akin to a group of well-intentioned and often slightly better-off citizens than people's voice on health issues. A participant in a focus group with ordinary citizens captured the essence of this argument:

the population listens to the HFC members, but they first have to wait that the local authorities finish saying what they have to say, and then they leave some time to the HFC. (FG population, B02, 2013)

The qualitative research also found that in a vast majority of HFCs (91.6\%), HFC members are often members of local school, water, Red Cross, and other NGO-initiated committees. This, in practice, could facilitate the transmission of HF information but also suggest that a particular type of citizen 'monopolises' (or is assigned to) participatory institutions and that HFC members could be somewhat generic representatives who appear to have (some) cultural capital but not necessarily the social and political capital that characterises community leaders.

Analysing the focus group discussions, it became clear that the HFC was usually not a central actor at the community level, even in matters related to health: HFC members and the general population alike stressed that the most influential people are local politicians and religious leaders. Local governance in Burundi remains highly hierarchical. Addressing an assembly requires the endorsement of at least one of two key actors: chefs de colline (elected hill chiefs) or church leaders. Although representatives of the HF population, HFC members do not have a 'natural' forum such as a church service or a colline (hill) gathering and therefore piggyback on existing meetings. "Organising meetings is not easy, but we use the colline meetings" explained HFC members (FG HFC, B31, 2013). In fact, many HFCs said that they simply could not organise meetings without using the local authorities. As an HFC president puts it: "organising a meeting without the intervention of the chef de colline is very complicated, even impossible" (interview HFC president, B03, 2013). The relationship between the HFC and the population is in practice mediated by the local politicians "who are the ones who communicate with the population" (interview pastor, B15, 2013). Similarly, religious leaders are key players for the HFC as they help communicate messages to the population. Since churches occupy 
a central place in social life, they are crucial for the mobilisation that precedes the election of the HFC but also for reaching the population once the committee is in place. As a Protestant minister put it: "people are believers, and apart from farming in the fields, they do not do much and come to the church" (interview pastor, B41, 2013). Interviews with HF users highlight that a strong committee is seen as one that is in contact with the churches and local authorities and is known by them.

A primary school director sums up what seems to be the general impression of the HFC: "it is useful, but I cannot say it is efficient because it is not in a position to take important decisions". (interview school director, B10, 2013).

\section{Concluding Remarks}

The main story that emerges is one of political elites bypassing, ignoring, and, more rarely, actively undermining citizens committees. It is consistent with Gaynor (2014) and Nicaise (2019), who show that the decentralisation process in Burundi has consolidated local political elites' rather than citizens' power, and with Sheely (2015), who provides experimental evidence that elite control can adapt to attempts to increase mobilisation and participation. The HFCs of Burundi are not places of significant power: their members have next to no influence at the HF, and they appear stuck in that situation. The apparent lack of interest of local politicians for the HFC, and the lack of substantial direct attempts to control it, should be a cause of concern. In a context where local political elites are typically considered opportunity-seekers, it is perhaps the best evidence that the HFC institution is not perceived as influential and has little chance of becoming so. It reveals issues with the HFCs' setup: laws conferring them power and training sessions are insufficient to make them effective. The stakes are too low for the local political elite to intervene: as the literature on Burundi suggests, such elite's way of exerting influence does not usually run through committees, and they do not bother interacting with an institution unthreatening to their influence. The HFCs also appear a long way from including marginalised groups or their champions, which would be necessary for them to pretend to be genuinely transformative (King 2015). However, resolving the deadlock situation with the HFCs may require more than inclusive, representative, competent, dynamic, and well-connected HFC members in the context of post-conflict Burundi marked by hierarchical relationships to chiefs (Laely 2014), entrenched identity party politics (Van Acker et al. 2018), and the decisive influence of top-down regional and national institutions and leaders on local service provision and public life (Nkurunziza 2011; Van Leeuwen et al. 2020). Burundi has changed since the study, but it would be hard not to see in the findings the evidence that the politicians' clampdown on community dynamics started well before the 2015 failed coup attempt. The real risk this paper points to is that the committee only serves a cosmetic function as an embodiment of itself that does not serve anyone's interests. It is a clear call for advocates of community participation to look more closely at how committees are governed in practice and go beyond simple representativeness and participation metrics. 
The relative failure of the committee system in the case of Burundi does not necessarily mean that the approach is pointless: our study mostly shows that relatively low-cost and standard interventions for reinforcing the HFC are not sufficient in the short run and that striking an alliance with local leaders for achieving such goal is complicated. Our paper does not engage with another more long-run goal often put forward by community participation advocates: the promotion of democracy. However, what appears clear is that efficient committees and participation require both bolstering the HFC capacity and upper-level changes. Fox (2015) argues that a 'sandwich' strategy is needed: public interest advocacy needs to encounter a reformist attitude from above. Hickey and King (2016) have a similar argument when they discuss the need to strengthen and legitimise public authorities to promote bottomup forms of accountability. As HFC members mention it themselves, the focus may also need to be on the 'middle', that is on peers and local notables who are not far remote from committee members: "without the local leaders, it would be really hard for us to connect with the population" (FG HFC, B36, 2013).

The literature on community participation warns against hasty generalisations (McCoy et al. 2012), and Burundi may be particularly stark a case of top-down authoritarianism hampering community governance initiatives. However, many other so-called 'fragile' contexts share not too dissimilar socio-political characteristics, especially when peace rests on complex political settlements. As in Burundi, the difficulty of capturing political elites for the committee, rather than the elite capture of the committee, may be a crucial impediment to the development of meaningful social accountability mechanisms. Given that committee-based strategies are heavily promoted by international aid (Bealt and Mansouri 2018), our paper invites to caution and to pay attention not only to the responsiveness of the health system and health providers to participatory mechanisms (Lodenstein et al. 2017), but also to the ways in which committee governance 'fits'-disrupts or, in our case, often does not seem even to touch-the pre-existing local politics and dynamics of accountability that shape basic social services delivery. In a forthcoming paper that looks at the case of HFCs in Eastern DR Congo, we further contribute to such agenda and stress the importance of the type of relationship to authorities (top-down or else), but much more research in more contexts, and in particular a synthesis of evidence, would be necessary to advance policies and research in this field.

\section{Appendix}

See Tables 4, 5, 6, 7 and Fig. 2. 


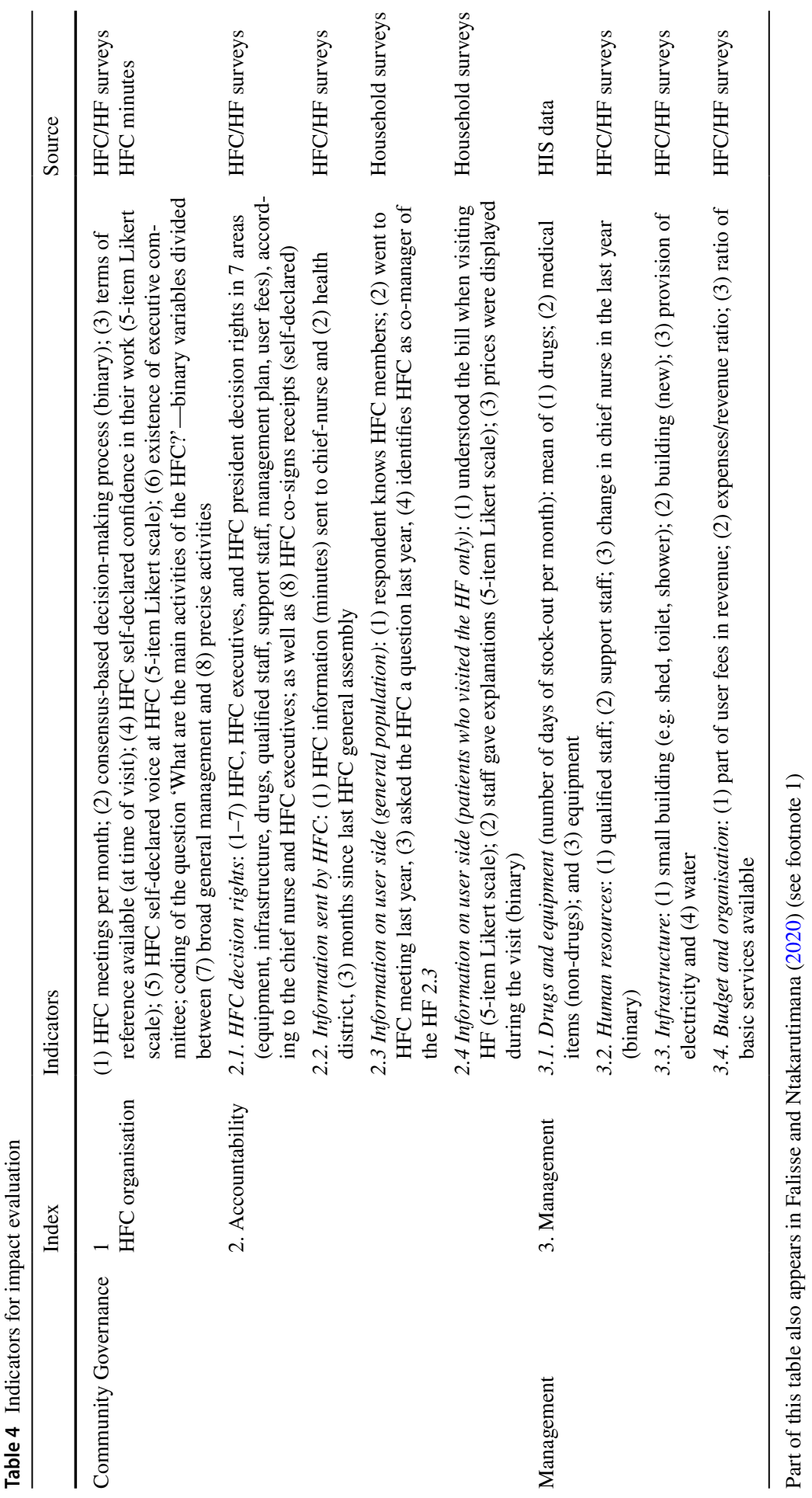




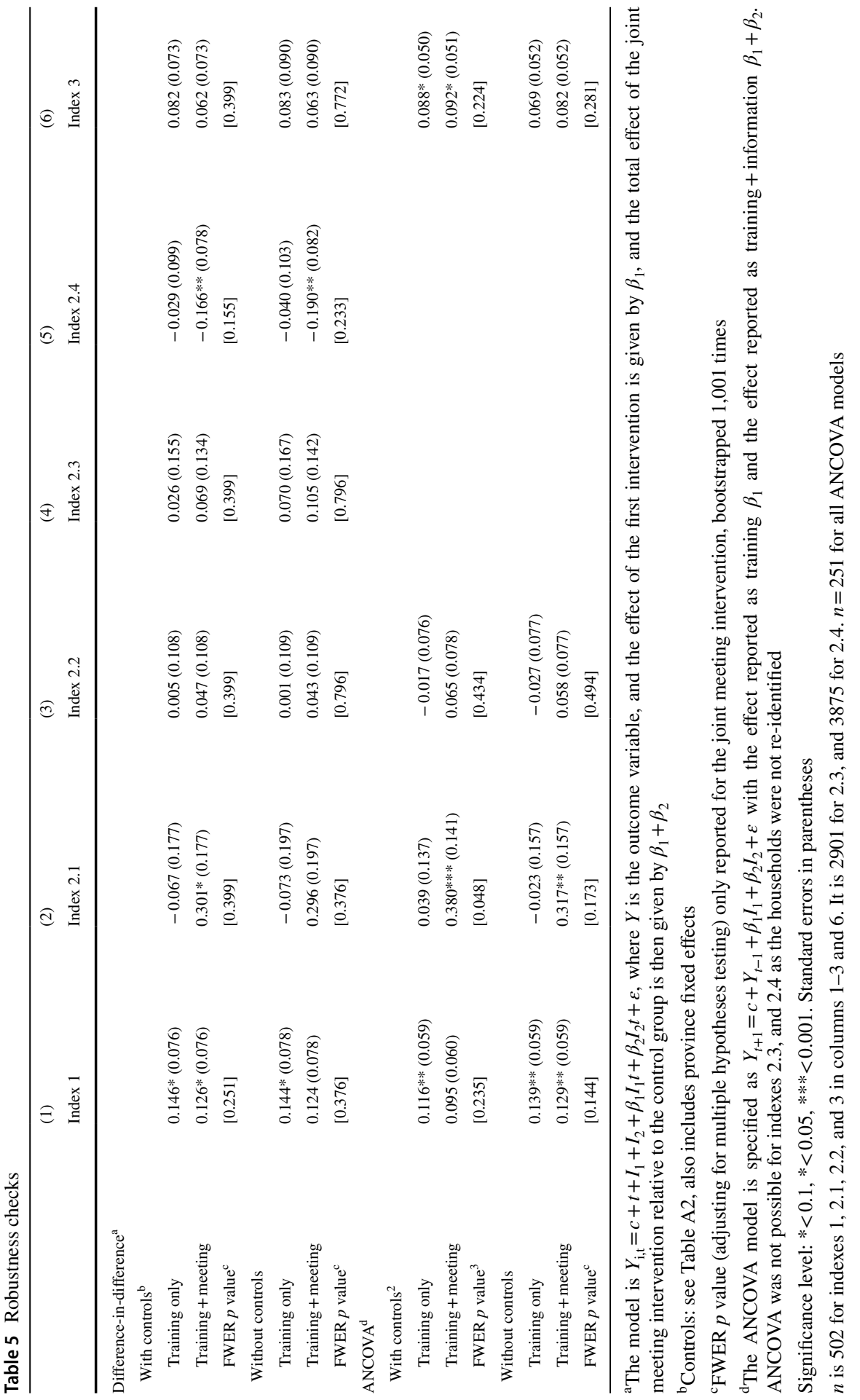

尔 
Table 6 Joint meeting intervention: effects on HF/HFC accountability

(1) diff-diff

(2) ANCOVA

\begin{tabular}{|c|c|c|}
\hline \multicolumn{3}{|c|}{$\begin{array}{l}\text { Decision rights at } \mathrm{HF} \text { (mean value: } 0=\text { no right: } 1=\text { is } \\
\text { asked advice; } 2=\text { involved in decision) }{ }^{\mathrm{a}}\end{array}$} \\
\hline HFC president-according to chief-nurse & $0.052(0.098)$ & $0.051(0.075)$ \\
\hline HFC president-according to HFC president & $0.055(0.093)$ & $0.033(0.065)$ \\
\hline HFC executives-according to chief-nurse & $0.208 * *(0.096)$ & $0.216 * * *(0.076)$ \\
\hline HFC executives-according to HFC president & $0.125(0.100)$ & $0.172 * *(0.070)$ \\
\hline HFC members-according to chief-nurse & $0.092(0.088)$ & $0.138 *(0.076)$ \\
\hline HFC members-according to HFC president & $0.118(0.083)$ & $0.109 *(0.065)$ \\
\hline HFC co-signs orders $(1=$ yes $)$ & $0.025(0.114)$ & $0.071(0.088)$ \\
\hline \multicolumn{3}{|l|}{ 2.3. Accountability: users' experience at $\mathrm{HF}^{\mathrm{b}}$} \\
\hline Tariffs were displayed $(1=$ yes $)$ & $-0.049(0.083)$ & \\
\hline Understood staff explanations (5-item Likert) & $-0.296(0.255)$ & \\
\hline Clear bills (5-item Likert scale) & $-0.173(0.149)$ & \\
\hline
\end{tabular}

See Table A3 for model specification

${ }^{\mathrm{a}} n=502$ in column 1 and $\mathrm{n}=251$ in column 2

${ }^{\mathrm{b}} n=3683$ for tariffs, $n=2850$ for understood staff, and $n=3804$ for clear bills

Significance level: $*<0.1, *<0.05, * * *<0.001$. standard error in parentheses

Table 7 Simple OLS regression models

\begin{tabular}{llllll}
\hline & $(1)$ & $(2)$ & $(3)$ & $(4)$ & $(5)$ \\
& Index 1 & Index 2.1 & Index 2.2 & Index 2.3 & Index 2.4 \\
\hline Ratio of politicians in HFC & $-0.196^{*}$ & 0.084 & -0.148 & $-0.469^{* *}$ & -0.040 \\
& $(0.103)$ & $(0.203)$ & $(0.155)$ & $(0.195)$ & $(0.108)$ \\
Ratio of HFC members went to & -0.102 & -0.010 & 0.094 & $-0.277^{*}$ & -0.017 \\
secondary school & $(0.090)$ & $(0.177)$ & $(0.135)$ & $(0.143)$ & $(0.086)$ \\
Ratio women in HFC & -0.139 & -0.069 & 0.204 & $-0.438^{* *}$ & -0.088 \\
& $(0.105)$ & $(0.207)$ & $(0.158)$ & $(0.198)$ & $(0.115)$ \\
Controls ${ }^{\mathrm{a}}$ & $(0.000)$ & $(0.000)$ & $(0.000)$ & $(0.000)$ & $(0.000)$ \\
Province fixed effects & Yes & Yes & Yes & Yes & Yes \\
Household controls & N/A & N/A & Yes & Yes & N/A \\
Survey sampling & N/A & N/A & Yes & Yes & N/A \\
$N$ & 249 & 249 & 249 & 1417 & 1452 \\
Adjusted. $R^{2}$ & 0.046 & 0.366 & 0.089 & & \\
\hline
\end{tabular}

Standard errors in parentheses

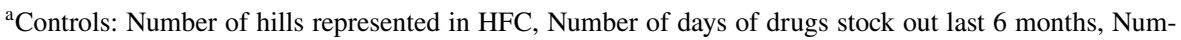
ber of HFC members, Number of HF staff members, Days without electricity last month

${ }^{\mathrm{b}}$ Household controls: gender, age, education, farmer

Significance level: $*<0.1, *<0.05, * * *<0.001$ 


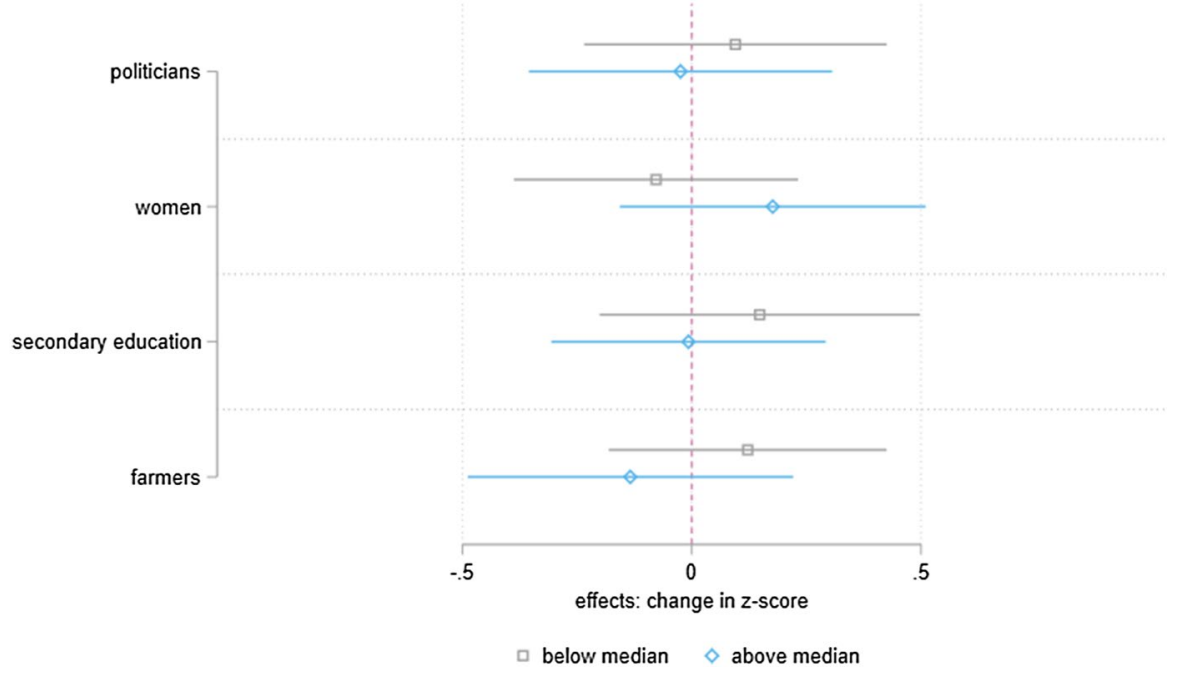

Fig. 2 Heterogeneous effects of the interventions on HFC rights (index 2.1) by committee membership, training intervention only

Effects are all relative to the control group, lines are standard errors. If the line touches the dotted red vertical line, the effect is not significant at $p<0.1$. IA dummy variable taking the value 1 if the HFCs is above the mean in terms of ratio of politicians, women, secondary education, (subsistence farmers) among its members. That dummy variable was then interacted with the intervention variable in the ANCOVA model. The figure, therefore, shows the effects of the training intervention depending on the membership of the committee (the low number of HFC that benefitted from the joint meeting intervention does not allow such analysis)

Acknowledgements We would like to thank Pierre Bakevya, Bernard Nyagashahu, Freddy Irambona, and Isidore Nkunzimana who brilliantly led the implantation of the action-research project 'Inama n'amagara', which included, among others, the Randomised Control Trial described in this paper. The project was made possible by to the consortium COPED-Cordaid, led by Emmanuel Ndayegamiye and Michel Bossuyt. The European Union, initially via Pierre-Antoine Cavert and then Pascal Crépin, proved to be a patient and understanding funder. Of course, none of this would have been possible without our exceptional team of enumerators and drivers (special thanks go to Placide Nibogora, Egide Nduwimana for their work as coordinators). Clayton Boeyink kindly proofread our manuscript. Jean-Benoit Falisse is also obliged to the Oxford Department of International Development and St Antony's College for their financial support during his $\mathrm{PhD}$. JBF and $\mathrm{HN}$ both contributed to the original design and led the data collection, JBF led the analysis and writing, which HN revised and approved. Dataset and replication files: see corresponding author's ORCID page.

Funding Funding was provided by Directorate-General for Development and Cooperation - EuropeAid (Grant No. 2011/262-857).

\section{Declarations}

Conflict of interest On behalf of all authors, the corresponding author states that there is no conflict of interest.

Open Access This article is licensed under a Creative Commons Attribution 4.0 International License, which permits use, sharing, adaptation, distribution and reproduction in any medium or format, as long as you give appropriate credit to the original author(s) and the source, provide a link to the Creative Commons licence, and indicate if changes were made. The images or other third party material in this article 
are included in the article's Creative Commons licence, unless indicated otherwise in a credit line to the material. If material is not included in the article's Creative Commons licence and your intended use is not permitted by statutory regulation or exceeds the permitted use, you will need to obtain permission directly from the copyright holder. To view a copy of this licence, visit http://creativecommons.org/licen ses/by/4.0/.

\section{References}

Bealt, J., and S.A. Mansouri. 2018. From disaster to development: A systematic review of communitydriven humanitarian logistics. Wiley Online Library 42 (1): 124-148. https://doi.org/10.1111/disa. 12232.

Casey, K., R. Glennerster, and E. Miguel. 2012. Reshaping institutions: Evidence on aid impacts using a pre-analysis plan. Quarterly Journal of Economics 127 (4): 1755-1812.

Dasgupta, A., and V.A. Beard. 2007. Community driven development, collective action and elite capture in Indonesia. Development and Change 38 (2): 229-249. https://doi.org/10.1111/j.1467-7660.2007. 00410.x.

Falisse, J.-B. 2019. Beyond the travelling model? Strategic usage and hybridisation of performance-based financing (PBF) in health in Burundi. Politique Africaine 156 (4): 83-100.

Falisse, J.-B., B. Meessen, J. Ndayishimiye, and M. Bossuyt. 2012. Community participation and voice mechanisms under performance-based financing schemes in Burundi. Tropical Medicine \& International Health 17 (5): 674-682. https://doi.org/10.1111/j.1365-3156.2012.02973.x.

Falisse, J.-B., and L. Ntakarutimana. 2020. When information is not power: Community-elected health facility committees and health facility performance indicators. Social Science and Medicine. https:// doi.org/10.1016/j.socscimed.2020.113331.

Fox, J. A. 2015. Social accountability: What does the evidence really say? World Development 72: 346361. https://doi.org/10.1016/j.worlddev.2015.03.011.

Gaynor, N. 2014. Bringing the citizen back supporting decentralisation in fragile states - A view from Burundi. Development Policy Review 32 (2): 203-218. https://doi.org/10.1111/dpr.12051.

Guerzovich, F. 2020. Conquering our blind spots: Glamorising the everyday politics of accountability. GPSA Blog. https://gpsaknowledge.org/blog/conquering-our-blind-spots-glamorizing-the-everydaypolitics-of-accountability-part-1/.

Hickey, S., and S. King. 2016. Understanding social accountability: Politics, power and building new social contracts. The Journal of Development Studies 52 (8): 1.

King, S. 2015. Increasing the power of the poor? NGO-led social accountability initiatives and political capabilities in rural Uganda. European Journal of Development Research 27 (5): 887-902. https:// doi.org/10.1057/ejdr.2014.74.

Kohlhagen, D. 2009. Burundi: La justice en milieu rural. Bujumbura: RCN Justice \& Democratie.

Laely, T. 2014. Peasants, local communities, and central power in Burundi. The Journal of Modern African Studies 35 (4): 695-716.

Lieberman, E.S. 2005. Nested analysis as a mixed-method strategy for comparative research. American Political Science Review 99 (3): 435-452.

Lodenstein, E., M. Dieleman, B. Gerretsen, and J.E.W. Broerse. 2017. Health provider responsiveness to social accountability initiatives in low- and middle-income countries: A realist review. Health Policy and Planning 32 (1): 125-140. https://doi.org/10.1093/heapol/czw089.

Manor, J. 2004. User committees: A potentially damaging second wave of decentralisation? European Journal of Development Research 16 (1): 192-213. https://doi.org/10.1080/095788104100016 88806.

Mansuri, G., and V. Rao. 2004. Community-based and -driven development: A critical review. The World Bank Research Observer 19 (1): 1-39. https://doi.org/10.1093/wbro/lkh012.

Mansuri, G., and V. Rao. 2012. Localising development. Does participation? Work localizing development. Washington: World Bank.

McCoy, D.C., J.A. Hall, and M. Ridge. 2012. A systematic review of the literature for evidence on health facility committees in low- and middle-income countries. Health Policy and Planning 27 (6): 449466. https://doi.org/10.1093/heapol/czr077. 
McKenzie, D. 2012. Beyond baseline and follow-up: The case for more $\mathrm{T}$ in experiments. Journal of Development Economics 99 (2): 210-221. https://doi.org/10.1016/j.jdeveco.2012.01.002.

Minah, M., and Malvido Pérez. Carletti. 2019. Mechanisms of inclusion: Evidence from Zambia's farmer organisations. European Journal of Development Research 31 (5): 1318-1340. https://doi.org/10. 1057/s41287-019-00212-8.

Nicaise, G. 2019. Local power dynamics and petty corruption in Burundi. Journal of Eastern African Studies 13 (4): 698-717. https://doi.org/10.1080/17531055.2019.1655880.

Niyongabo, P., R. Douwes, M. Dieleman, F. Irambona, J. Mategeko, G. Nsengiyumva, and T. De Cock Buning. 2018. Ways and channels for voice regarding perceptions of maternal health care services within the communities of the Makamba and Kayanza provinces in the Republic of Burundi: An exploratory study. BMC Health Services Research 18 (1): 46. https://doi.org/10.1186/ s12913-017-2822-y.

Nkurunziza, J. 2011. Inequalities and post-conflict policies in Burundi. In Horizontal inequalities and post-conflict development, ed. F. Stewart, A. Langer, and R. Venugopal, 209-229. Palgrave Mcmillan.

Osmani, S. 2008. Participatory governance: An overview of issues and evidence. In Building trust through civic engagement, 9-44. Geneva: United Nations.

Platteau, J.-P. 2004. Monitoring elite capture in community-driven development. Development and Change 35 (2): 223-246. https://doi.org/10.1111/j.1467-7660.2004.00350.x.

Platteau, J.-P., and F. Gaspart. 2013. Disciplining local leaders in community-based development. Centre for Research on the Economics of Development (CRED) Working Paper. Namur: University of Namur, Department of Economics.

Rajasekhar, D., M.D. Babu, and R. Manjula. 2018. Decentralised governance, development programmes and elite capture. Decentralised Governance, Development Programmes and Elite Capture. https:// doi.org/10.1007/978-981-13-1900-6.

Ramiro, L., F. Castillo, T. Tan-Torres, C. Torres, J. Tayag, R. Talampas, and L. Hawken. 2001. Community participation in local health boards in a decentralized setting: Cases from the philippines. Health Policy and Planning 16 (suppl 2): 61-69.

Rusca, M., K. Schwartz, L. Hadzovic, and R. Ahlers. 2015. Adapting generic models through bricolage: Elite capture of water users associations in peri-urban Lilongwe. European Journal of Development Research 27 (5): 777-792. https://doi.org/10.1057/ejdr.2014.58.

Sabates-Wheeler, R., N. Wilmink, A.G. Abdulai, R. de Groot, and T. Spadafora. 2020. Linking social rights to active citizenship for the most vulnerable: The role of rights and accountability in the 'making' and 'shaping' of social protection. European Journal of Development Research 32 (1): 129-151. https://doi.org/10.1057/s41287-019-00223-5.

Sepehri, A., and J. Pettigrew. 1996. Primary health care, community participation and community-financing: Experiences of two middle hill villages in Nepal. Health Policy and Planning 11 (1): 93-100.

Sheely, R. 2015. Mobilisation, participatory planning institutions, and elite capture: Evidence from a field experiment in rural Kenya. World Development 67: 251-266. https://doi.org/10.1016/j.worlddev. 2014.10.024.

Uvin, P., and L. Bayer. 2013. Political economy of statebuilding in Burundi. In Political economy of statebuilding: Power after peace, ed. M. Berdal and D. Zaum, 263-275. Routeledge.

Van Acker, T., J. Muhangaje, and O.-A. Magerano. 2018. Partisan identity politics in post-war Burundi. In Conjonctures de l'Afrique Centrale, ed. S. Geenen, A. Nyenyezi Bisoka, and S. Alidou, 71-90. Paris: L'Harmattan.

Van Leeuwen, M., J. Nindorera, J.L. Kambale Nzweve, and C. Corbijn. 2020. The 'local turn' and notions of conflict and peacebuilding-Reflections on local peace committees in Burundi and eastern DR Congo. Peacebuilding 8 (3): 279-299. https://doi.org/10.1080/21647259.2019.1633760.

Vandeginste, S. 2015. Arusha at 15: reflections on power-sharing, peace and transition in Burundi. Institute of Development Policy and Management Discussion Paper. Antwerp: Institute of Development Policy and Management.

Warren, C., and L. Visser. 2016. the local turn: An introductory essay revisiting leadership, elite capture and good governance in indonesian conservation and development programs. Human Ecology 44 (3): 277-286. https://doi.org/10.1007/s10745-016-9831-z.

Wong, S. 2012. Elite capture or capture elites? Lessons from the 'counter-elite'and 'co-optelite'approaches in Bangladesh and Ghana. In The role of elites in economic development, ed. A. Hoffenberg Amsden, A. DiCaprio, and J.A. Robinson. Oxford: Oxford University Press. 
Publisher's Note Springer Nature remains neutral with regard to jurisdictional claims in published maps and institutional affiliations. 